\title{
Bait efficiency to monitor mandi (Pimelodus maculatus) in the tailrace of hydropower dams, Southeast Brazil
}

\author{
Eficiência de iscas no monitoramento do mandi (Pimelodus maculatus) no canal de fuga
} de usinas hidrelétricas no sudeste do Brasil

\author{
Alexandre Peressin ${ }^{1,2 *}$ (D), Rafael Couto Rosa Souza ${ }^{2}$ (D) and Alexandre Lima Godinho ${ }^{3}$ \\ ${ }^{1}$ Programa de Pós-graduação em Ecologia Aplicada, Departamento de Ecologia e Conservação, \\ Universidade Federal de Lavras - UFLA, Campus Universitario, CEP 37200-000, Lavras, MG, \\ Brasil \\ ${ }^{2}$ Programa Peixe Vivo, Companhia Energética de Minas Gerais - CEMIG, Av. Barbacena, 1200, \\ Santo Agostinho, CEP 30190-131, Belo Horizonte, MG, Brasil \\ ${ }^{3}$ Centro de Transposição de Peixes, Universidade Federal de Minas Gerais - UFMG, Av. Presidente \\ Antônio Carlos, 6627, CEP 31270-901, Belo Horizonte, MG, Brasil \\ *e-mail: alexandre.peressin@gmail.com
}

Cite as: Peressin, A., Souza, R.C.R. and Godinho, A.L. Bait efficiency to monitor mandi (Pimelodus maculatus) in the tailrace of hydropower dams, Southeast Brazil. Acta Limnologica Brasiliensia, 2021, 33, e8.

\begin{abstract}
This study compared the efficiency of two baits (earthworm and cow heart) for monitoring the abundance of mandi catfish (Pimelodus maculatus) in the tailrace of hydropower dams, one of the commonly killed fish in turbine procedures. Sampling occurred every two months from February 2014 to December 2015 at the Camargos and Itutinga hydropower dams, located in the upper Paraná River basin, using hooks baited with earthworm and cow heart. We used generalized linear models to test the influence of dam, bait type, dam outflow discharge, water temperature, transparency, and dissolved oxygen on mandi abundance, calculated as catch per unit effort. Most mandi (73\%) were caught using earthworms but catch per unit effort of mandi for both baits showed the same pattern of seasonal variation at each dam. At both dams, individuals of mandi sampled using earthworms were smaller than those sampled using cow heart, and water temperature was the only environmental variable significantly associated with the catch per unit effort of mandi. Both baits are efficient to monitor seasonal variations in mandi abundance, which is influenced by water temperature. Monitoring the abundance of mandi in the tailrace can help minimizing fish mortality by scheduling risky turbine procedures for periods of lower mandi abundance.
\end{abstract}

Keywords: fish sampling; lure preference; fish mortality; turbine procedure.

Resumo: O estudo comparou a eficiência de duas iscas (minhoca e coraçáo de boi) no monitoramento da abundância do mandi (Pimelodus maculatus) no canal de fuga de barragens hidrelétricas, um dos peixes mais frequentemente mortos por manobras de turbinas. As amostragens foram bimestrais, de fevereiro de 2014 a dezembro de 2015, nas usinas hidrelétricas de Camargos e Itutinga, rio Grande, bacia do alto rio Paraná, usando anzóis iscados com minhoca e coração de boi. Usamos modelos lineares generalizados para testar a influência da usina hidrelétrica, tipo de isca, vazão defluente, temperatura, transparência e oxigênio dissolvido da água na abundância calculada pela captura por unidade de esforço de mandis. A maioria dos mandis (73\%) foi capturada usando minhoca, mas as capturas por unidade de esforço verificadas para as duas iscas mostraram o mesmo 
padrão de variação sazonal nas duas usinas. Em ambas as usinas, os mandis capturados com minhoca foram menores que aqueles capturados com coração de boi, e a temperatura da água foi a única variável ambiental significativamente associada à abundância de mandis. As duas iscas sáo eficientes para monitorar variaçóes sazonais na abundância do mandi, que é influenciada apenas pela temperatura da água. Monitorar a abundância do mandi no canal de fuga pode auxiliar na redução da mortalidade de peixes, programando manobras arriscadas de turbinas para períodos de menor abundância do mandi.

Palavras-chave: amostragem de peixes; preferência por isca; mortalidade de peixe, manobra de turbina.

Mortality of fish in the tailrace is frequent in Brazilian hydropower dams during turbine procedures, such as start-up or dewatering, as fish in the tailrace may come into the turbine area (Rêgo et al., 2017). This mortality can range from less than a kilogram to up to tons of fish in a single turbine procedure (Andrade et al., 2012). A variety of fish species may be killed during such turbine procedures (Rêgo et al., 2017), but the mandi catfish (Pimelodus maculatus Lacepède, 1803) is by far the species most frequently killed in some basins (Andrade et al., 2012; Rêgo et al., 2017).

The abundance of mandi in the tailrace is a predictor for the number of mandi at risk of death during turbine procedure (Andrade et al., 2012). Thus, monitoring the abundance of mandi in the tailrace can help minimizing fish mortality (Loures et al., 2017) by scheduling turbine procedures for periods of lower mandi abundance. Therefore, sound understanding of the seasonal variation in mandi abundance in the tailrace is necessary for this strategy to be successful.

Sampling with gillnets is one of the most common techniques used for determining fish abundance (Oliveira et al., 2014). Gillnets can be used in many tailraces, but not in those with high turbulent flow, where baited hook may represent the only option for sampling fish (Loures et al., 2017). Sampling fish with baited hook also results in lower bycatch than gillnetting because baited hooks are more species selective than gillnets, which is important for studies that require abundance data on target species (Elliott \& Beamesderfer, 1992). In this way, our objectives were to (i) evaluate differences in the number and length of sampled mandi using earthworm and cow hear - baits most commonly used by local fishermen (personal observation of the authors), (ii) compare seasonal variation in catches, and (iii) determine the abiotic factors that influence the number of sampled mandi.

We carried out this study at the Camargos and Itutinga hydropower dams, located in the Grande River, upper Paraná River basin, Brazil. Camargos $\left(21^{\circ} 19^{\prime} 30^{\prime \prime} \mathrm{S}, 44^{\circ} 36^{\prime} 58^{\prime \prime} \mathrm{W}\right)$ is the most upstream hydropower dam of the Grande River; Itutinga $\left(21^{\circ} 17^{\prime} 30^{\prime \prime} \mathrm{S}, 44^{\circ} 37^{\prime} 31^{\prime \prime} \mathrm{W}\right)$ is located $7.5 \mathrm{~km}$ downstream from Camargos. Both dams have no fishway. The tailrace of Camargos is $51 \mathrm{~m}$ wide and $8 \mathrm{~m}$ deep, while Itutinga is $52 \mathrm{~m}$ wide and $8 \mathrm{~m}$ deep. The mean and the daily outflow discharge interval $\left(\mathrm{m}^{3} \cdot \mathrm{s}^{-1}\right)$ during the study period was 51 and 24-182 in Camargos, and 61 and 32-191 in Itutinga.

We sampled fish at both dams every two months from February 2014 to December 2015. No sampling occurred at Itutinga hydropower dam in August 2014 as turbine procedures precluded the use of baited hooks. Sampling consisted of throwing the baited hook from the powerhouse into the tailrace near the exit of the draft tubes. We used $1.68 \mathrm{~m}$ long fiberglass rods, reels with $100 \mathrm{~m}$ of $0.35 \mathrm{~mm}$ diameter line, $35 \mathrm{~g}$ of lead, and size 2 hooks $(270 \mathrm{~mm}$ long, $11 \mathrm{~mm}$ gape, $1 \mathrm{~mm}$ diameter), manufactured with high-carbon steel. We used the hook size 2 because it captured mandi of similar mean weight $(118 \mathrm{~g})$ of those collected in the turbine during the dewatering procedures $(101 \mathrm{~g}$; personal observation of the authors). When baiting with earthworms, we ensured that the bait covered the entire length of the hook. We baited hooks with strips or cubes of cow heart about the same width as the hook gape $(11 \mathrm{~mm})$. We used commercially raised earthworms (Annelida: Glossoscolecidae) purchased in a local market. Earthworms were approximately $54 \times 3 \mathrm{~mm}$, while cow heart bait cubes were $27 \times 11 \times 3 \mathrm{~mm}$.

The fishing effort consisted of two experienced fishers, each fishing at the same time for periods of $4 \mathrm{~h}$ between 7:30 and 17:00 h. The catch per unit effort (CPUE) was calculated as CPUE $=\frac{\text { number of mandi }}{\text { number of fishers } \mathrm{x} \text { hour }}$. Before fishing, we randomly selected one fisher to sample with earthworm while the other used cow heart. After every hour of sampling and until the end of the 4-h sampling period, the fishers alternated the type of bait they used. We ensured that the fishers were spaced 5-15 $\mathrm{m}$ from each other and that the baited hooks were lying on the tailrace bottom, 3-10 m 
from the tailrace edge, at a depth of approximately $8 \mathrm{~m}$ at Camargos and $6 \mathrm{~m}$ at Itutinga.

We recorded the standard length (SL) of every mandi captured, and released them at the capture site. Sampling had the authorization from the Ministry of the Environment, Brazil's federal environmental agency (ICMBio license \#10306).

Between 9:00-16:00, we measured water temperature and dissolved oxygen (DO) using an YSI 550A probe, and water transparency using a Secchi disk. We obtained data on the dam outflow discharge from the Telemetry and Hydrometeorological Monitoring System of the hydropower dam concessionaire, the Power Company of Minas Gerais (Companhia Energética de Minas Gerais; CEMIG).

To avoid pseudoreplication, we used autocorrelation analysis to verify the temporal independence of samples for all variables used in statistical tests. We performed this analysis using the autocorrelation function (ACF) available in the $\mathrm{R}$ software. We used a generalized linear model (GLM) with a negative binomial distribution to determine the influence of dam, bait type, dam outflow discharge, water temperature, DO, and water transparency on the CPUE of sampled mandi. We assessed overdispersion using the ratio between the residual deviance and the degrees of freedom. We considered overdispersion appropriate when the ratio was between $0-1$. In the final model, we included only significant variables. We used the Mann-Whitney test to evaluate differences in mandi SL between the two bait types for each dam. We performed all analysis in the software RStudio ( $R$ Development Core Team, 2019). We adopted the level of significance $(\alpha)$ of 0.05 .

Mandi represented $73 \%$ of all fish sampled at Camargos and $90 \%$ of those captured at Itutinga. Besides mandi, we captured seven other species at Camargos (Psalidodon aff fasciatus, Brycon orbignyanus, Iheringichthys labrosus, Megaleporinus piavussu, Piabarchus stramineus, Pimelodus microstoma, and Salminus brasiliensis), and eight at Itutinga (B. orbignyanus, Imparfinis mirini, Leporinus friderici, L. octofasciatus, $M$. piavussu, $P$. microstoma, S. brasiliensis, and Schizodon nasutus).

All autocorrelations were lower than the 95\% confidence interval and, therefore, not significant. Considering that even among independent samples 1 in 20 autocorrelations might be significant (Kendall et al., 1983), we concluded that all variables we used came from independent samples (Zuur et al., 2010).
At both dams, we captured more mandi using earthworms (Camargos $=0.58$; Itutinga $=1.2$ mandi per fisher per hour) than using cow heart (Camargos $=0.13$; Itutinga $=0.67$ mandi per fisher per hour) (GLM, $\mathrm{p}=0.04)$. Water temperature was the only limnological variable that explained significant variation in the number of mandi sampled through time (GLM, p < 0.01). There was no significant interaction among any pair of variables analyzed by the GLM, including the interaction between dam and water temperature. No interaction between dam and water temperature indicated that temperature had similar effects on the number of mandi sampled through time at both dams, which is also supported by graphical analysis (Figure 1).

Considering both dams, CPUE per sample ranged from 0.00 to 6.12 , averaging 2.44 mandi per fisher per hour. The CPUE of sampled mandi using earthworms and cow heart showed the same pattern of seasonal variation at both dams, with higher CPUEs from December to April (Figure 1). Thus, both baits seem to indicate a period of the year when mandi abundance in the tailrace is greatest, and therefore, when turbine procedures are riskier to fish. It is well known that the behavior of Neotropical riverine fishes is influenced by environmental variables, like temperature, which affects several aspects of their biology (e.g., feeding, migration, reproduction, interactions, and life history) and abundance (Lowe-McConnell, 1987). High CPUE values occurred during warm months from November to February (Loures \& Pompeu, 2012),

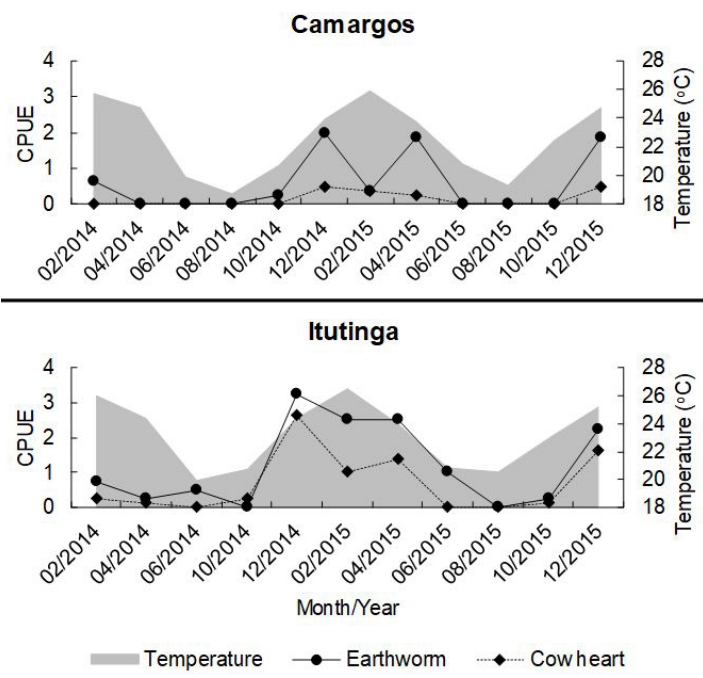

Figure 1. Seasonal variation of water temperature and catch per unit effort (CPUE) of mandi (Pimelodus maculatus) sampled by bait type in the tailrace of the Camargos and Itutinga hydropower dams. 
coinciding with the spawning season of mandi in the upper Paraná River basin (Agostinho et al., 2003). Mandi is usually classified as a migratory fish (Agostinho et al., 2003), but this behavior is controversial and some authors consider mandi as sedentary (Oldani et al., 2007). Peressin et al. (2017) verified that $95 \%$ of the mandi females from the tailrace of 12 dams of the upper Paraná River basin, including Camargos and Itutinga, had undeveloped gonads. This suggests that mandi at the tailrace of dams are not migrating for spawning and could be there for other purposes, like dispersal or feeding (Godinho \& Kynard, 2009).

The SL of the mandi captured using earthworms (range: $7.1-29.8 \mathrm{~cm}$; mean: $14.9 \mathrm{~cm}$ ) was significantly smaller than the SL of the mandi sampled using cow heart (range: 11.5-33.0; mean: $19.4 \mathrm{~cm}$ ) at both dams (Mann-Whitney test; $\mathrm{p}<0.01$; Figure 2). Thus, combining both baits provides samples across a broader size range. The volume (size and shape) of bait types is also known to affect the size of fish captured with hooks (Hayes et al., 2012). We could not cut cow hearts into pieces of the same size and shape as earthworms for every sampling campaign because the size of earthworms varied slightly by season. Therefore, differences in the SL of mandi caught using the two different bait types could also be due to the differences in size and shape between the two bait types.

\section{Camargos}

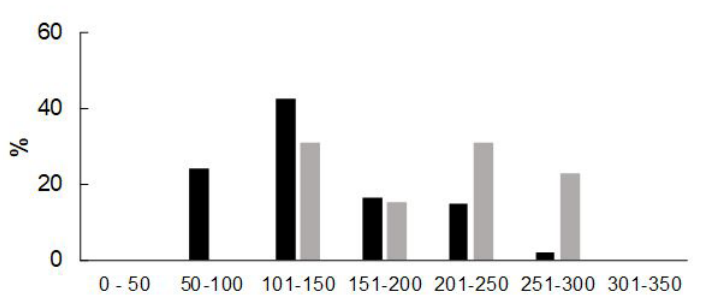

Itutinga

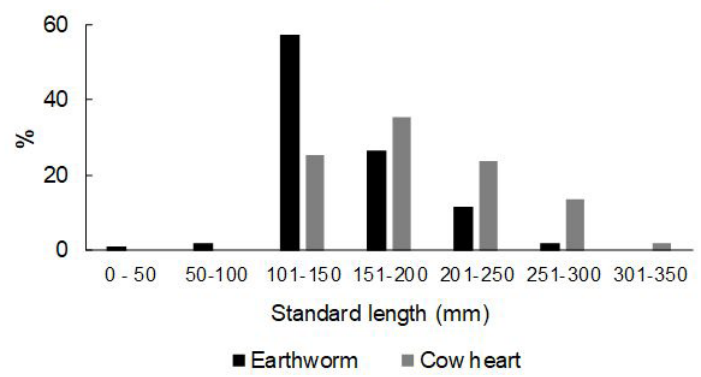

Figure 2. Percentages of mandi (Pimelodus maculatus) by classes of standard length (SL) sampled with earthworms or cow heart in the tailrace of the Camargos and Itutinga hydropower dams.
In conclusion, baited hooks with earthworms and cow heart can be successfully applied in tailraces with highly turbulent flow to monitor variation in mandi abundance. Both baits should be used to cover a broader range of sizes. Hooks baited with either type of bait can be used to monitor seasonal variation of mandi abundance in the tailrace of hydropower dams. This information is helpful to reduce fish mortality by scheduling turbine procedures to periods when mandi abundance is lower.

\section{Acknowledgements}

We thank the Peixe Vivo Program of CEMIG for logistical and financial support. We also thank the environmental analysts and technicians from the Camargos and Itutinga hydropower dams for their support during sampling.

\section{References}

AGOSTINHO, A.A., GOMES, L.C., SUZUKI, H.I. and JÚLIO-JÚNIOR, H.F. Migratory fishes of the upper Paraná river basin, Brazil. In: J. CAROLSFELD, B. HARVEY, C. ROSS and A. BAER, eds. Migratory Fishes of South America: biology, fisheries and conservation status. Otawa: IDRC-World Bank, 2003, pp. 19-98.

ANDRADE, F., PRADO, I.G., LOURES, R.C. and GODINHO, A.L. Evaluation of techniques used to protect tailrace fishes during turbine maneuvers at Três Marias Dam, Brazil. Neotropical Ichthyology, 2012, 10(4), 723-730. http://dx.doi.org/10.1590/ S1679-62252012000400005.

ELLIOTT, J.C. and BEAMESDERFER, R.C. Comparison of efficiency and selectivity of three gears used to sample white sturgeon in a Columbia River reservoir. In: R.C. BEAMESDERFER and A.A. NIGRO, eds. Status and habitat requirements of the white sturgeon populations in the Columbia River downstream from McNary Dam. Portland, Oregon: U.S. Department of Energy, 1992, pp. 17-29. Final Report of Research.

GODINHO, A.L. and KYNARD, B. Migratory fishes of Brazil: life history and fish passage needs. River Research and Applications, 2009, 25(6), 702-712. http://dx.doi.org/10.1002/rra.1180.

HAYES, W.A., FERRERI, C.P. and TAYLOR, W.W. Active fish capture methods. In: A.V. ZALE, D.L. PARRISH and T.M. SUTTON, eds. Fisheries techniques. Bethesda, USA: American Fisheries Society, 2012, pp. 193-220.

KENDALL, M.G., STUART, A. and ORD, J.K. Advanced theory of statistics. 4th ed. London: Charles Griffin, 1983, vol. 3: Design and analysis, and timeseries. 
LOURES, R.C., GODINHO, A.L., SILVA, R.J., ANDRADE, F.R., RÊGO, A.C.L., CARVALHO, M.M., PRADO, I.G., ARAÚJO, A.R., SILVA, T.T., RODRIGUES, R.R. and RESENDE, L.C. Methodology for risk assessment of fish death at hydropower plants. In: R.C. LOURES and GODINHO, A.L., eds. Risk assessment of fish death at hydropower plants in southeastern Brazil [online]. Belo Horizonte: CEMIG, 2017 [viewed 14 Apr 2020], pp. 37-70. Available from: http://www.cemig. com.br/ptbr/A_Cemig_e_o_Futuro/sustentabilidade/nossos_ programas/ ambientais/peixe_vivo/publicacoes/ Paginas/serie_peixe_vivo.aspx

LOURES, R.C.F. and POMPEU, P.S. Temporal variation in fish community in the tailrace of the Três Marias Hydroelectric Dam, São Francisco River, Brazil. Neotropical Ichthyology, 2012, 10(4), 731-740. http:// dx.doi.org/10.1590/S1679-62252012000400006.

LOWE-MCCONNELL, R.H. Ecological studies in tropical fish communities. Cambridge: Cambridge University Press, 1987, 382 pp. http://dx.doi. org/10.1017/CBO9780511721892.

OLDANI, N.O., BAIGÚN, C.R.M., NESTLER, J.M. and GOODWIN, R.A. Is fish passage technology saving fish resources in the lower La Plata River basin? Neotropical Ichthyology, 2007, 5(2), 89-102. http:// dx.doi.org/10.1590/S1679-62252007000200002.

OLIVEIRA, A.G., GOMES, L.C., LATINI, J.D. and AGOSTINHO, A.A. Implications of using a variety of fishing strategies and sampling techniques across different biotopes to determine fish species composition and diversity. Natureza \& Conservação, 2014, 12(2), 112-117. http://dx.doi.org/10.1016/j. ncon.2014.08.004.

PERESSIN, A., PRADO, I.G., RESENDE, L.C., SILVA, T.T., CALDEIRA, Y.M. and GODINHO, A.L. Biology of mandi (Pimelodus maculatus) immediately downstream of hydropower plants of southeastern Brazil. In: LOURES, R.C. and A. L. GODINHO, eds. Risk assessment of fish death at hydropower plants in southeastern Brazil [online]. Belo Horizonte: CEMIG, 2017 [viewed 14 Apr 2020]. pp. 155-178. Available from: http://www.cemig.com.br/ pt-br/A_Cemig_e_o_Futuro/sustentabilidade/nossos _programas/ambientais/peixe_vivo/publicacoes/ Paginas/serie_peixe_vivo.aspx

R DEVELOPMENT CORE TEAM. $R$ : A language and environment for statistical computing [online]. Vienna: R Foundation for Statistical Computing, 2019 [viewed 14 Apr 2020]. Available from: https:// www.R-project.org/

RÊGO, A.C.L., PRADO, I.G., SILVA, T.T., LOURES, R.C., SILVA, R.J., MONTEIRO, A.B. and GODINHO, A.L. Fish affected by operational procedures of hydropower plants in southeastern Brazil. In: R.C. LOURES and A.L. GODINHO, eds. Risk assessment of fish death at hydropower plants in southeastern Brazil [online]. Belo Horizonte: CEMIG, 2017 [viewed 14 Apr 2020]. pp. 71-96. Available from: from: http://www.cemig.com.br/ pt-br/A_Cemig_e_o_Futuro/sustentabilidade/nossos _programas/ambientais/peixe_vivo/publicacoes/ Paginas/serie_peixe_vivo.aspx

ZUUR, A.F., IENO, E.N. and ELPHICK, C.S. A protocol for data exploration to avoid common statistical problems. Methods in Ecology and Evolution, 2010, 1(1), 3-14. http://dx.doi.org/10.1111/j.2041210X.2009.00001.x.

Received: 14 April 2020 Accepted: 30 March 2021

Associate Editor: Fernando Mayer Pelicice. 